\title{
EFFECT OF FUNGICIDE ON THE DEVELOPMENT OF WHEAT STEM RUST AND YIELD OF WHEAT VARIETIES IN HIGHLANDS OF ETHIOPIA
}

\author{
K. TADESSE, A. AYALEW ${ }^{1}$ and A. BADEBO ${ }^{2}$ \\ Oromia Agricultural Research Institute, Sinana Agricultural Research Centre, \\ P.O. Box 208, Bale-Robe, Ethiopia \\ ${ }^{1}$ Department of Plant Sciences, Haramaya University, P.O. Box 241, Haramaya, Ethiopia \\ ${ }^{2}$ Ethiopian Institute of Agricultural Research, Debre-Zeit Agricultural Research Centre, \\ P.O. Box 32, Debre-Zeit, Ethiopia \\ Corresponding author: amareayalew@yahoo.com
}

(Received 21 October, 2009; accepted 15 February, 2010)

\begin{abstract}
Stem rust caused by Puccinia graminis f.sp tritici Erik. \& E. Henn. is a highly destructive disease of wheat (Triticum aestivum L.). The effects of fungicide application on stem rust (Puccinia graminis tritici) epidemics and yield of three bread wheat varieties varying in reaction to the disease were studied in two major wheat growing and stem rust prone districts (Agarfa and Sinana) of Bale, Ethiopia. Disease onset was late, generally after ear emergence, at both locations; but stem rust severity increased at high rates and terminal severity levels up to 81, 72 and 37\% at Agarfa, and up to 37, 32 and 14\% at Sinana were recorded on the varieties Sirbo, Maddawalabu and FH4-2-11, respectively. The rates of infection and AUDPC values of stem rust on the varieties were significantly $(\mathrm{P}<0.05)$ reduced by the fungicide sprays. The disease resulted in relative grain yield losses of up to $29 \%$ at Agarfa and 22\% at Sinana on unsprayed plots. Thousand kernel weight reductions of up to $25.4 \%$ at Agarfa and $19.2 \%$ at Sinana were recorded. Generally, only the weekly fungicide application gave nearly complete control on the varieties.
\end{abstract}

Key Words: AUDPC, Puccinia graminis tritici, Triticum aestivum

\section{RÉSUMÉ}

La maladie de la rouille causée par Puccinia graminis tritici f.sp Erik. \& E. Henn. est une maladie extrêmement destructrice de blé (Triticum aestivum L.). Les effets de l'application de fungicides sur les (Puccinia graminis tritici) épidemies de la rouille et le rendement de trois variétés de blé à réaction variée à la maladie était étudiés dans deux districts grands producteurs de blé et prône aux maladies de la rouille (Agarfa et Sinana) de Bale, Ethiopie. La maladie était apparue tard après l'apparution d'épis dans les deux sites, mais la sévérité de la rouille augmentait à un taux élevé. Les niveaux fatals de sévérité de 81,72 et 37\% à Agarfa, et 37, 32 et $14 \%$ à Sianana étaient respectivement enregistrés sur les variétés Sirbo, Maddawalabu et FH4-2-1. Les taux d'infection et les valeurs de “AUDPC" de la rouille sur les variétés étaient significativement réduits $(\mathrm{P}<0,05)$ par la pulvérisation de fongicides. La Maladie à entrainé une perte de rendement allant jusqu’ à $29 \%$ à Agarfa et $22 \%$ à sinana dans les parcelles non traitées. Les réductions du poids de 1000 grains allant jusqu'à 25,4\% à Agarfa et 19,2\% à sinana ont été aussi notées. En général, seule l'application hebdomadaire du fungicide a conduit à un contrôle presque total de la rouille sur les variétés. Le rendement des cultures dans les parcelles traitées avec fongicides était invariablement supérieur à celui des parcelles témoins.

Mots Clés: AUDPC, Puccinia graminis tritici, Triticum aestivum 


\section{INTRODUCTION}

Stem rust caused by Puccinia graminis f.sp tritici Erik. \& E. Henn. is a highly destructive disease of wheat. Under favourable conditions, stem rust can cause yield losses of up to $100 \%$ in susceptible varieties (Roelfs, 1985a; Leonard and Szabo, 2005). Through the widespread use of resistant varieties, however, stem rust is currently largely under control worldwide except in eastern Africa. For reasons that are not fully understood, but probably related to climate and the continuous cultivation of wheat throughout the year, eastern Africa has been a spawning ground for new physiological races of wheat rusts (CIMMYT, 2005).

A new stem rust race designated as Ug99 has been detected in Uganda in 1999 (Pretorius et al., 2000). Race Ug99 is virulent on a number of stem rust resistant genes, most notably $\mathrm{Sr} 31$ for which Ug99 was the first reported virulent race. Sr31 has been widely employed in CIMMYT wheat germplasm, cultivated in different parts of the world (Badebo, 2002). Stem rust isolates with virulence on $\mathrm{Sr} 31$ are already widespread in the eastern African highlands and pose immediate danger to wheat production in the region (CIMMYT, 2005; Wanyera et al., 2006).

Trials conducted during 2000 to 2004 in different areas of Ethiopia showed that stem rust has been increasing. The major strategy for the management of stem rust in Ethiopia would remain focused on the development of resistant varieties. On the other hand, the large-scale wheat growers in Arsi and Bale regions have extensively used fungicides to control rusts, spending around 0.5 million US dollars on chemicals annually (CIMMYT, 2005).

It is well established that better understanding of the epidemiology of plant diseases is necessary for the development of reliable and effective disease management systems. The role of pragmatic approaches of analysis of disease progress in evaluating disease management practices for various pathosystems has been summarised by a recent review (Jeger, 2004). Although stem rust is one of the most widely studied plant diseases in most parts of the world, much remains to be learned to optimise management of the disease in Ethiopia, one of the few countries where the disease still continues to be a major factor limiting wheat production. This paper reports on development of stem rust epidemics on three bread wheat varieties differing in reaction to the disease under multiple levels of the disease created by different fungicide treatments.

\section{MATERIALS AND METHODS}

Field experiments were undertaken at two locations in Bale highlands of Ethiopia under rainfed conditions during 2005 and 2006 main cropping seasons.

Experimental sites. The experiments were conducted on a research station at Sinana and on farmer's field at Agarfa. Sinana is located at $7^{\circ}$ $7^{\prime} \mathrm{N}, 40^{\circ} 10^{\prime} \mathrm{E}$ and at 2450 meters above sea level (masl). Sinana receives mean annual rainfall of $808 \mathrm{~mm}$. The monthly mean minimum and maximum temperatures are 9.3 and $20.9{ }^{\circ} \mathrm{C}$, respectively. The dominant soil type is pellic vertisol which is slightly acidic.

Agarfa is located at $7^{\circ} 17^{\prime} \mathrm{N}, 39^{\circ} 49^{\prime} \mathrm{E}$ and 2530 masl. Its average annual rainfall is $833 \mathrm{~mm}$. The minimum and maximum temperatures are 7.3 and $22.8^{\circ} \mathrm{C}$, recpecitvely.

Both locations represent major wheat-growing and stem rust prone areas in the highlands of Bale. They are also characterised by bimodal rainfall, the short rainy season extending from March to July and the main season from August to December.

Wheat varieties. Three bread wheat varieties, namely Sirbo, Maddawalabu, and FH4-2-11, were used. They differ in reactions to stem rust with Sirbo as susceptible, Maddawalabu as moderately susceptible and FH4-2-11 as moderately resistant to the disease (SARC, 2004; Tadesse, 2005). The varieties have been resistant to other wheat diseases in the area such as yellow rust (SARC, 2004).

Fungicide treatments. Propiconazole (Tilt ${ }^{\circledR} 250$ E.C.) was applied at $0.5 \mathrm{l}$ product ha $\mathrm{h}^{-1}$ in different spray schedules. Treated plots received sprays every 7, 14, 21 and 28 days in which the first spray was done $0,14,21$ and 28 days, respectively, 
after the appearance of stem rust symptoms. During fungicide sprays, plastic sheets were used to separate the plot being sprayed from the adjacent plots. Unsprayed plots of each variety were included.

Field experiments. The experiments were laid out in randomised complete block design (RCBD) with factorial arrangement in three replications. Wheat varieties were planted at the recommended rate of $150 \mathrm{~kg}$ seed ha-1 to eight rowed plots of 5 $\mathrm{m}$ length with $20 \mathrm{~cm}$ inter-row spacing. The gaps between plots and replications were $1.5 \mathrm{~m}$ and 2 $\mathrm{m}$ wide, respectively. Spreader rows consisting of a mixture of different susceptible bread wheat varieties bordered each plot in order to ensure uniform spread of inoculum and sufficient disease development. Recommended rates of $41 \mathrm{~kg} \mathrm{ha}^{-1}$ $\mathrm{N}$ and $46 \mathrm{~kg} \mathrm{ha}^{-1} \mathrm{P}_{2} \mathrm{O}_{5}$ were applied during planting. Weeds were controlled by two to three times hand weeding.

Disease assessment. Stem rust severity, estimated as proportion of the stem of a plant affected by the disease, was assessed at weekly interval from the time of symptom appearance to physiological maturity of the crop. Severity was recorded using the modified Cobb's scale (Peterson et al., 1948), by assessing 10 randomly pre-tagged plants. The average stem rust severity from the 10 plants of each plot was used for analysis. During disease assessment, the growth stage of the crop was recorded to observe onset and progress of the disease in relation to wheat phenology. Crop growth stage was assessed based on the decimalised key developed by Zadoks et al. (1974).

Analysis of disease progress. The integral models, i.e. area under the disease progress curve (AUDPC), and growth curve functions were used. AUDPC values were calculated for each plot using the following formula (Wilcoxson et al., 1975):

$A U D P C=\sum_{i=1}^{n-1} 0.5\left(x_{i+1}+x_{i}\right)\left(t_{i+1}-t_{i}\right)$

where, $\mathrm{X}_{\mathrm{i}}$ is the cumulative disease severity expressed as a proportion at the $i^{\text {th }}$ observation; $t_{i}$ is the time (days after planting) at the $i^{\text {th }}$ observation and $\mathrm{n}$ is total number of observations. Since the duration of assessment was not the same for each epidemic, AUDPC values were standardised through dividing the values by the total duration $\left(\mathrm{t}_{\mathrm{n}}-\mathrm{t}_{1}\right)$ of the epidemic.

Disease progress rates were estimated from the logistic function, ln [(Y/1-Y)] (Van der Plank, 1963). Prior comparison of the goodness of fit with the Gompertz model, - $\ln [-\ln (\mathrm{Y})]$ (Berger, 1981) showed that the logistic function is superior as indicated by generally higher coefficients of determination $\left(\mathrm{R}^{2}\right)$. The transformed data were regressed over time (number of days after planting) and the apparent rates of disease increase were derived.

Crop yield and thousand-kernel weight. Grain yield in grammes per plot at $12.5 \%$ moisture content was recorded. Only six rows of the internal rows of the plots were harvested for yield estimations, excluding $0.5 \mathrm{~m}$ on both sides along the length of the plot. The weight of thousand kernels sampled at random from the total grains harvested from each experimental plot was also measured.

Statistical analysis. Data on stem rust severity, AUDPC, rate of disease increase yield and yield components were subjected to analysis of variance using IRRISTAT software (IRRI, 2003). Least Significant Difference (LSD 0.05) was employed to compare treatment means.

Yield loss estimation. The relative losses in yield and yield component of each variety were determined as a percentage of that of the protected plots of the respective variety. Losses were calculated separately for each of the treatments with different levels of disease, as:

$R L(\%)=\frac{\left(Y_{1}-Y_{2}\right)}{Y_{1}} \times 100$

Where, $\mathrm{RL}=$ relative loss (reduction of the parameters grain yield and TKW), $\mathrm{Y}_{1}=$ mean of the respective parameter on protected plots (plots with maximum protection) and $\mathrm{Y}_{2}=$ mean of the respective parameter in unprotected plots (i.e. unsprayed plots or sprayed plots with varying level of disease). 


\section{RESULTS}

Epidemic onset and severity level. Stem rust was first observed at relatively later growth stages of the varieties. Both at Agarfa and Sinana, the disease appeared on variety Sirbo around the completion of ear emergence (growth stage GS 57-59). On variety Maddawalabu, stem rust was first observed at about GS 69 (flowering complete) at Agarfa, and at GS 61 at Sinana. The disease was observed on FH4-2-11 at GS 65 (flowering half way) at Agarfa, while at slightly earlier growth stage (GS 59-61) at Sinana (data not presented).

Under natural epidemics (no spray) at Agarfa, terminal severity levels were $81 \%$ on Sirbo, $72 \%$ on Maddawalabu and 37\% on FH4-2-11 in 2005, whereas these levels were about 50, 34 and 9\%, respectively in 2006 (Table 1). There were significant $(\mathrm{P}<0.05)$ variations among the varieties in levels of severity of stem rust, with the exception of Sirbo and Maddawalabu in 2005 at Agarfa. Lower levels of stem rust severity were observed at Sinana than Agarfa during both seasons. At Sinana, stem rust severities of about 41,32 and $14 \%$ were recorded on unsprayed plots of varieties Sirbo, Maddawalabu and FH4-2-11 in 2006 whereas the corresponding values (19, 24 and 1.4\%) were lower in 2005.

Area under disease progress curve. There were significant $(\mathrm{P}<0.05)$ differences in AUDPC values among varieties as well as fungicide treatments, both at Agarfa and Sinana in both seasons (Table 2). At Agarfa, the highest standardised AUDPC values (38.5 in 2005 and 23.6 in 2006) were observed on unsprayed plots of variety Sirbo; these values were significantly reduced by fungicide sprays at 7,14 and 21 days interval. On variety Maddawalabu at Agarfa, AUDPC values of 35.6 and 17.1 were recorded on unsprayed plots in 2005 and 2006, respectively. On Maddawalabu, only the sprays at 7 and 14 days interval showed significant effect on AUDPC. At Agarfa, the fungicide treatments at 7 and 14 days interval significantly reduced AUDPC values on the variety FH4-2-11; the 21 days interval treatment

TABLE 1. Terminal stem rust severity levels on three bread wheat varieties with different fungicide spray schedules at Agarfa and Sinana, 2005 and 2006 main season in Ethiopia

\begin{tabular}{|c|c|c|c|c|c|}
\hline \multirow[t]{3}{*}{ Variety } & \multirow{3}{*}{$\begin{array}{l}\text { Fungicide spray } \\
\text { interval (days) }\end{array}$} & \multicolumn{4}{|c|}{ Terminal stem rust severity (\%) } \\
\hline & & \multicolumn{2}{|c|}{2005} & \multicolumn{2}{|c|}{2006} \\
\hline & & Agarfa & Sinana & Agarfa & Sinana \\
\hline \multirow[t]{5}{*}{ FH4-2-11 } & 7 & 1.6 & 0.0 & 0.0 & 0.0 \\
\hline & 14 & 12.4 & 0.6 & 4.9 & 5.5 \\
\hline & 21 & 17.4 & 1.0 & 6.4 & 9.3 \\
\hline & 28 & 37.5 & 1.3 & 8.7 & 12.1 \\
\hline & No spray & 37.3 & 1.4 & 9.3 & 13.7 \\
\hline \multirow[t]{5}{*}{ Maddawalabu } & 7 & 2.2 & 0.0 & 0.0 & 0.0 \\
\hline & 14 & 36.8 & 12.6 & 17.6 & 20.3 \\
\hline & 21 & 55.3 & 14.9 & 30.6 & 26.8 \\
\hline & 28 & 64.0 & 19.0 & 37.0 & 30.4 \\
\hline & No spray & 71.7 & 24.1 & 34.3 & 31.8 \\
\hline \multirow[t]{5}{*}{ Sirbo } & 7 & 0.7 & 0.0 & 0.0 & 0.0 \\
\hline & 14 & 44.3 & 5.8 & 24.4 & 26.3 \\
\hline & 21 & 46.2 & 11.6 & 40.4 & 33.8 \\
\hline & 28 & 69.7 & 13.7 & 50.3 & 37.1 \\
\hline & No spray & 80.7 & 19.0 & 49.3 & 40.7 \\
\hline $\operatorname{LSD}(0.05)$ & & 11.4 & 1.01 & 9.81 & 8.34 \\
\hline
\end{tabular}


also showed significant effect in 2005. AUDPC values on this variety without fungicide treatment were 19.1 in 2005 and 4.5 in 2006.

At Sinana, the AUDPC values on variety FH42-11 were low (less than 1 ) in 2005, while values up to 7.1 were recorded in 2006 (Table 2). AUDPC values of 7.7 and 15.8 were recorded for unsprayed plots of variety Maddawalabu in 2005 and 2006, respectively, while the corresponding values were 5.5 and 21.3 on variety Sirbo (Table 2). In 2005 at Sinana, fungicide treatments at 7 and 14 days interval significantly reduced AUDPC on the varieties Maddawalabu and Sirbo. In 2006, these treatments showed significant effect on AUDPC in all three varieties.

Infection rate. Only the weekly fungicide sprays significantly reduced infection rate of stem rust on the varieties (Table 3). The only exception was FH4-2-11 in 2005 at Sinana, on which none of the fungicide treatments had significant effect on the infection rate. In weekly sprayed plots, the rate of infection did not exceed 0.01 units day $^{-1}$ at Sinana, while it reached about 0.04 units day $^{-1}$ at Agarfa (Table 3). In the unsprayed plots of variety Sirbo at Agarfa, stem rust was increasing at 0.15 and 0.22 units day ${ }^{-1}$ in 2005 and 2006, respectively. In unsprayed plots of Maddawalabu at Agarfa, stem rust progressed at 0.14 units day ${ }^{-1}$ in 2005 and 0.20 units day ${ }^{-1}$ in 2006. Infection rates of 0.12 units day ${ }^{-1}$ in 2005 and 0.13 in 2006 were recorded from unsprayed plots of FH4-2-11 (Table 3).

At Sinana, the rate of stem rust infection was relatively lower. On unsprayed plots of Sirbo and Maddawalabu, stem rust progressed at a rate of 0.13 units day ${ }^{-1}$ in 2005, while the rates were 0.16 and 0.15 , respectively, in 2006 (Table 3). The rate of stem rust increase on FH4-2-11 in 2005 at Sinana was not affected by the fungicide treatments. In the unsprayed plots, the rate reached 0.05 units day $^{-1}$, which was not significantly different from the weekly sprayed plots of the other varieties. In 2006, the disease increase rate on FH4-2-11

TABLE 2. Standardised* area under disease progress curve (AUDPC) for stem rust on three bread wheat varieties under different fungicide spray schedules at Agarfa and Sinana, 2005 and 2006 main crop seasons in Ethiopia

\begin{tabular}{|c|c|c|c|c|c|}
\hline \multirow[t]{2}{*}{ Variety } & \multirow{2}{*}{$\begin{array}{l}\text { Fungicide spray } \\
\text { interval (days) }\end{array}$} & \multicolumn{2}{|c|}{2005} & \multicolumn{2}{|c|}{2006} \\
\hline & & Agarfa & Sinana & Agarfa & Sinana \\
\hline \multirow[t]{5}{*}{ FH4-2-11 } & 7 & 1.87 & 0.05 & 0.12 & 0.24 \\
\hline & 14 & 5.33 & 0.44 & 3.27 & 2.79 \\
\hline & 21 & 10.92 & 0.45 & 3.82 & 5.36 \\
\hline & 28 & 20.17 & 0.55 & 4.63 & 6.88 \\
\hline & No spray & 19.12 & 0.55 & 4.5 & 7.07 \\
\hline \multirow{5}{*}{ Maddawalabu } & 7 & 2.39 & 0.03 & 0.08 & 0.21 \\
\hline & 14 & 25.19 & 4.24 & 10.55 & 12.19 \\
\hline & 21 & 32.39 & 6.89 & 16.62 & 14.79 \\
\hline & 28 & 32.53 & 7.06 & 18.58 & 15.06 \\
\hline & No spray & 35.64 & 7.65 & 17.13 & 15.75 \\
\hline \multirow[t]{5}{*}{ Sirbo } & 7 & 0.92 & 0.09 & 0.12 & 0.21 \\
\hline & 14 & 23.34 & 2.27 & 12.35 & 15.74 \\
\hline & 21 & 25.14 & 4.3 & 19.68 & 18.56 \\
\hline & 28 & 33.29 & 4.58 & 22.25 & 21.56 \\
\hline & No spray & 38.49 & 5.49 & 23.58 & 21.25 \\
\hline $\operatorname{LSD}(0.05)$ & & 6.65 & 2.82 & 0.95 & 0.97 \\
\hline
\end{tabular}

*AUDPC values divided by the total duration of the epidemic 
TABLE 3. Rate* (units day ${ }^{-1}$ ) of stem rust infection on three bread wheat varieties under different fungicide spray intervals at Agarfa and Sinana in Bale, Ethiopia, 2005 and 2006 main crop seasons in Ethiopia

\begin{tabular}{|c|c|c|c|c|c|}
\hline \multirow[t]{2}{*}{ Variety } & \multirow{2}{*}{$\begin{array}{l}\text { Fungicide spray } \\
\text { interval (days) }\end{array}$} & \multicolumn{2}{|c|}{2005} & \multicolumn{2}{|c|}{2006} \\
\hline & & Agarfa & Sinana & Agarfa & Sinana \\
\hline \multirow[t]{5}{*}{ FH4-2-11 } & 7 & 0.015 & 0.011 & 0.03 & 0.01 \\
\hline & 14 & 0.072 & 0.039 & 0.09 & 0.06 \\
\hline & 21 & 0.078 & 0.060 & 0.10 & 0.09 \\
\hline & 28 & 0.113 & 0.041 & 0.13 & 0.09 \\
\hline & No spray & 0.122 & 0.050 & 0.13 & 0.11 \\
\hline \multirow[t]{5}{*}{ Maddawalabu } & 7 & 0.008 & -0.003 & 0.02 & 0.01 \\
\hline & 14 & 0.094 & 0.106 & 0.13 & 0.08 \\
\hline & 21 & 0.111 & 0.095 & 0.17 & 0.11 \\
\hline & 28 & 0.130 & 0.111 & 0.19 & 0.13 \\
\hline & No spray & 0.144 & 0.130 & 0.20 & 0.15 \\
\hline \multirow[t]{5}{*}{ Sirbo } & 7 & 0.035 & 0.006 & 0.01 & 0.01 \\
\hline & 14 & 0.101 & 0.100 & 0.18 & 0.10 \\
\hline & 21 & 0.127 & 0.119 & 0.20 & 0.11 \\
\hline & 28 & 0.152 & 0.117 & 0.21 & 0.13 \\
\hline & No spray & 0.150 & 0.130 & 0.22 & 0.16 \\
\hline $\operatorname{LSD}(0.05)$ & & 0.06 & 0.07 & 0.09 & 0.07 \\
\hline
\end{tabular}

*Calculated based on weekly assessment of disease severity from logistic function

reached 0.11 in unsprayed plots, comparable to the plots of Maddawalabu and Sirbo treated with fungicide at 21 days interval.

Effect on grain yield and yield component. Grain yield was significantly $(\mathrm{P}<0.05)$ increased by fungicide sprays on varieties Sirbo and Maddawalabu except at Sinana in 2005 (Table 4). In both varieties, the weekly fungicide treatment significantly increased grain yield. At Agarfa, the 14 days interval fungicide treatment provided a significant yield increase on variety Sirbo during both seasons. Relative yield losses due to stem rust reached $29 \%$ on variety Sirbo and $21.1 \%$ on Maddawalabu in 2005 at Agarfa. In 2006, grain yield losses were $25.7 \%$ on Sirbo and $18.6 \%$ on Maddawalabu. At Sinana, the effect of the disease on grain yield was not significant $(\mathrm{P}>0.05)$ during 2005. In 2006, the disease reduced grain yield by $22.1 \%$ on Sirbo and $18.1 \%$ on Maddawalabu (Table 5).

The 1000-kernel weight (TKW) of the varieties was significantly increased by fungicide treatments at Agarfa during both seasons and at Sinana in 2006. At Agarfa, maximum TKW losses of 20.1 and $25.4 \%$ were recorded on unsprayed plots of Sirbo and Maddawalabu, respectively (Table 4). At Sinana, the disease resulted in TKW reduction of $15.3 \%$ on Sirbo and $19.3 \%$ on Maddawalabu without fungicide treatment (Table 5).

\section{DISCUSSION}

The onset of stem rust was relatively late in relation to host growth stage. At Agarfa, variety Maddawalabu completed flowering by the time of disease appearance, while variety 'Sirbo' was late in ear emergence stage. Variety FH4-2-11 had about the same maturity as variety Maddawalabu. Also at Sinana, the disease first appeared at relatively later stages of wheat growth. Roelfs (1985a) described stem rust as a disease of the reproductive phase of wheat. With the presence of urediospores of stem rust pathogen trapped at earlier crop growth stage 
TABLE 4. Grain yield and thousand kernel weight of three bread wheat varieties and the corresponding relative losses ${ }^{\star}$ due to stem rust under different fungicide spray schedules at Agarfa, 2005 and 2006 main season in Ethiopia

\begin{tabular}{|c|c|c|c|c|c|c|c|c|c|}
\hline \multirow[t]{2}{*}{ Variety } & \multirow{2}{*}{$\begin{array}{l}\text { Fungicide } \\
\text { spray interval } \\
\text { (days) }\end{array}$} & \multicolumn{4}{|c|}{2005} & \multicolumn{4}{|c|}{2006} \\
\hline & & $\begin{array}{l}\text { Grain yield } \\
\qquad\left(\mathrm{kg} \mathrm{ha}^{-1}\right)\end{array}$ & $\begin{array}{r}\text { Loss } \\
(\%)\end{array}$ & $\begin{array}{c}\text { TKW}^{* *} \\
(\mathrm{~g})\end{array}$ & $\begin{array}{c}\text { Loss } \\
(\%)\end{array}$ & $\begin{array}{c}\text { Grain yield } \\
(\mathrm{kg} \mathrm{ha-1})\end{array}$ & $\begin{array}{c}\text { Loss } \\
(\%)\end{array}$ & $\begin{array}{c}\text { TKW** } \\
(\mathrm{g})\end{array}$ & $\begin{array}{c}\text { Loss } \\
(\%)\end{array}$ \\
\hline \multirow[t]{5}{*}{ FH4-2-11 } & 7 & 3908.1 & 0.0 & 38.7 & 0.0 & 4002.1 & 0.0 & 39.3 & 0.0 \\
\hline & 14 & 3462.3 & 11.4 & 38.1 & 1.6 & 3882.3 & 3.0 & 38.6 & 1.9 \\
\hline & 21 & 3422.3 & 12.4 & 37.8 & 2.3 & 3722.3 & 7.0 & 38.2 & 2.8 \\
\hline & 28 & 3611 & 7.6 & 37.4 & 3.4 & 3711 & 7.3 & 37.3 & 5.2 \\
\hline & No spray & 3292.7 & 15.8 & 36.9 & 4.7 & 3676 & 8.2 & 36.1 & 8.3 \\
\hline \multirow[t]{5}{*}{ Maddawalabu } & 7 & 4557 & 0.0 & 48.1 & 0.0 & 4536.5 & 0.0 & 48.3 & 0.0 \\
\hline & 14 & 4211.5 & 7.6 & 43 & 10.6 & 4115.5 & 9.3 & 44.5 & 7.8 \\
\hline & 21 & 4208.9 & 7.6 & 42.3 & 12.1 & 4076.2 & 10.2 & 42.8 & 11.4 \\
\hline & 28 & 3976.5 & 12.7 & 39.8 & 17.3 & 3909.9 & 13.8 & 41.1 & 15 \\
\hline & No spray & 3594.5 & 21.1 & 35.9 & 25.4 & 3694.7 & 18.6 & 37.4 & 22.6 \\
\hline \multirow[t]{5}{*}{ Sirbo } & 7 & 2993.7 & 0.0 & 37.6 & 0 & 3127.0 & 0.0 & 41 & 0.0 \\
\hline & 14 & 2824.4 & 5.7 & 36.8 & 2.1 & 2924.4 & 6.5 & 37.8 & 7.8 \\
\hline & 21 & 2562.5 & 14.4 & 36.8 & 2.1 & 2618.6 & 16.3 & 35.8 & 12.6 \\
\hline & 28 & 2638.3 & 11.9 & 35.2 & 6.4 & 2404.9 & 23.1 & 33.8 & 17.4 \\
\hline & No spray & 2123.2 & 29.1 & 31.6 & 16 & 2320.8 & 25.7 & 32.8 & 20.1 \\
\hline CV (\%) & & 11.2 & & 4.9 & & 7.9 & & 2.5 & \\
\hline LSD (5\%) & & 639.1 & & 3.1 & & 467.2 & & 2.6 & \\
\hline
\end{tabular}

*Losses calculated relative to yield or thousand-kernel weight of maximum protected plots (i.e., weekly sprayed)

**Thousand kernel weight

(data not presented), the late appearance of the disease is possibly related to unfavourable weather conditions particularly the cooler temperature till late October.

With final levels of stem rust severity reaching 81 and 72\%, respectively, varieties Maddawalabu and Sirbo, were severely attacked by the disease. Variety FH4-2-11, which has been considered as moderately resistant until recently (SARC, 2004; Tadesse, 2005) appeared to become moderately susceptible to stem rust under the heavy disease pressure at Agarfa in 2005, when severity reached $37 \%$. Regardless of the fungicide spray schedule, stem rust was less severe on the varieties at Sinana than at Agarfa. This was particularly obvious in the 2005 cropping season when low levels of stem rust severity were recorded at Sinana. In the 2006 cropping season, stem rust epidemics developed at Sinana although the terminal severity levels were still lower than at Agarfa. Weather conditions at Agarfa seemed to be conducive for development of the disease. The remarkable difference in the level of stem rust severity at Sinana between 2005 and 2006, on the other hand, is more likely related to the lower temperature condition recorded in 2005. Lower minimum and maximum temperatures were recoded in 2005 cropping season starting from September (Fig. 1); weather data were not available for Agarfa.

Although most of the fungicide spray schedules showed significant effects in reducing the level of stem rust severity and its rate of progression in all four field trials, only the weekly fungicide application ensured nearly complete control of stem rust development. During the 2005 epidemic at Agarfa, the sprays at 14 days interval reduced AUDPC on FH4-2-11 as effectively as the weekly sprays (AUDPC values were statistically at par).

Working with powdery mildew-pumpkin pathosystem, Everts (2002) also reported that a 
TABLE 5. Yield and yield components of three bread wheat varieties and the corresponding relative losses ${ }^{\star}$ due to stem rust under different fungicide spray schedules at Sinana, 2006 main season in Ethiopia

\begin{tabular}{|c|c|c|c|c|c|}
\hline Variety & $\begin{array}{l}\text { Fungicide spray } \\
\text { interval (days) }\end{array}$ & $\begin{array}{l}\text { Grain yield } \\
\left(\mathrm{kg} \mathrm{ha}^{-1}\right)\end{array}$ & $\begin{array}{l}\text { Loss } \\
(\%)\end{array}$ & $\begin{array}{l}\text { TKW** } \\
\text { (g) }\end{array}$ & $\begin{array}{l}\text { Loss } \\
(\%)\end{array}$ \\
\hline \multirow[t]{5}{*}{ FH4-2-11 } & 7 & 3727.1 & 0 & 34.6 & 0 \\
\hline & 14 & 3666.8 & 1.6 & 33.3 & 3.9 \\
\hline & 21 & 3593.4 & 3.6 & 33.6 & 3 \\
\hline & 28 & 3511.2 & 5.8 & 32.8 & 5.3 \\
\hline & No spray & 3523.2 & 5.5 & 32.5 & 6 \\
\hline \multirow[t]{5}{*}{ Maddawalabu } & 7 & 4728.6 & 0 & 46.2 & 0 \\
\hline & 14 & 4292.8 & 9.2 & 43.1 & 4.6 \\
\hline & 21 & 3997.7 & 15.5 & 41.2 & 8.8 \\
\hline & 28 & 4142.4 & 12.4 & 39.3 & 13.1 \\
\hline & No spray & 3874.6 & 18.1 & 37.1 & 19.3 \\
\hline \multirow[t]{5}{*}{ Sirbo } & 7 & 3186.3 & 0 & 36.1 & 0 \\
\hline & 14 & 2916.1 & 8.5 & 35 & 3.2 \\
\hline & 21 & 2638.5 & 17.2 & 32.6 & 9.7 \\
\hline & 28 & 2605.3 & 18.2 & 31.9 & 11.6 \\
\hline & No spray & 2482.9 & 22.1 & 30.6 & 15.3 \\
\hline CV (\%) & & 8.5 & & 3.1 & \\
\hline LSD (5 \%) & & 419.1 & & 1.9 & \\
\hline
\end{tabular}

*Losses calculated relative to yield or thousand-kernel weight of maximum protected plots (i.e. weekly sprayed) **Thousand kernel weight

reduced fungicide schedule (every 14 days) resulted in acceptable disease control on a moderately resistant cultivar grown under conditions favourable to the disease than a susceptible cultivar sprayed weekly. In the present study, the weekly application was started on the day the symptoms of stem rust were observed, while the first applications of the less frequent sprays were delayed by 14, 21 or 28 days for the corresponding spray intervals. From the significant reduction of AUDPC to one half as much as the control by fungicide sprays at 21 days interval, it is likely that more effective, and perhaps acceptable, disease control could be achieved by the less frequent fungicide sprays provided treatments were started at the time of disease appearance.

It is noteworthy that AUDPC of FH4-2-11 did not significantly $(\mathrm{P}>0.05)$ respond even to the weekly sprays under the low disease pressure at Sinana in 2005 indicating that fungicide intervention may not be necessary for this variety as long as the disease pressure remains low.

A pattern comparable to the variations in AUDPC among the different treatments was observed for the rate of infection of the disease. As pointed out by Campbell (1998), AUDPC and apparent infection rate are suited to answer specific questions about the epidemics to be compared; AUDPC shows the level of disease that induces stress during the season and can be used as predictor of yield; while infection rate answers the question 'does disease develop more rapidly in plots of treatment $\mathrm{A}$ than in plots of treatment B'.

The fungicide treatments (with the exception of the 28-days interval) were effective in markedly slowing down the progress of the disease. However, the fact that only the weekly fungicide treatments had statistically significant effect on rate of infection might be related to the delayed start of the less frequent sprays. For stem rust, it 


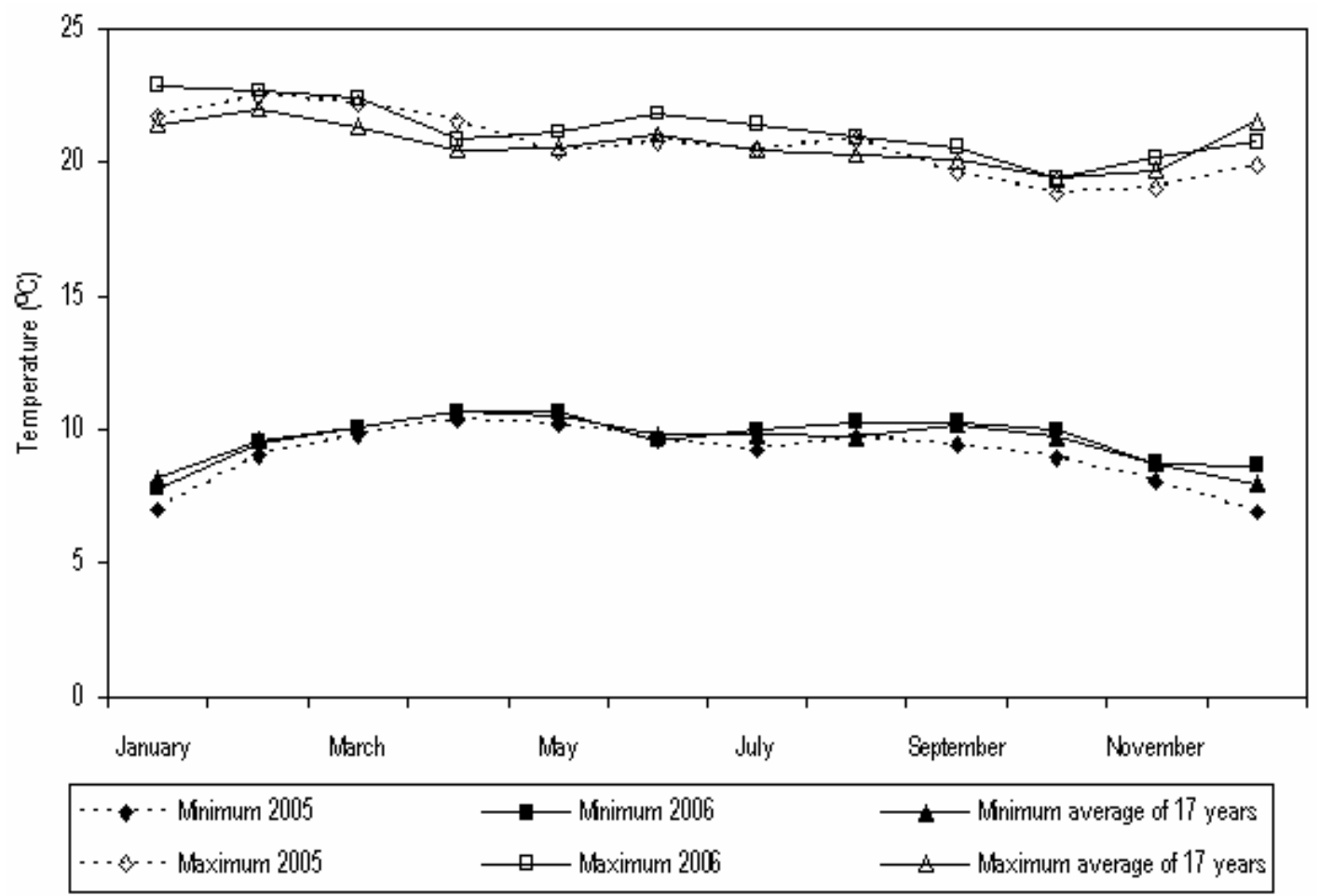

Figure 1. Minimum and maximum temperatures between the 2005 and 2006 cropping seasons and the average of 17 years (1990-2006) at Sinana in Ethiopia.

has been reported that fungicides reduced subsequent disease progress on plant parts that were slightly infected at the time of fungicide application, but they were not effective on plant parts that were heavily infected (Beard et al., 2004). Therefore, the stem rust control strategy through fungicide must consider the time of onset and early detection of the disease as the most important factor if economic control of the disease is intended (Roelfs, 1985b; Beard et al., 2004).

On the other hand, propiconazole has shown only minimal symplastic movement (transport in the living part), which implies poor control of disease at lower stem part following foliar application (Buchenauer, 1987). This might have also contributed to the reduced effect of the fungicide on further progress of stem rust when it was applied less frequently.

In general, the less frequent sprays allowed development of multiple levels of epidemics but were not effective in controlling the disease on
Maddawalabu and Sirbo; stem rust severity exceeded $20 \%$ within two weeks of its appearance (at the time of first application of the fortnightly sprays). These results reiterate the role of varietal resistance in determining the frequency and effectiveness of chemical sprays once rust is established.

The losses in grain yield on Sirbo (as high as 29\%) and Maddawalabu (up to 21.1\%) were comparable to earlier reports on susceptible varieties with late stem rust appearance (Luig, 1985; Beard et al., 2004). On FH4-2-11, losses in grain yield were generally less than $10 \%$, except in 2005 at Agarfa. Comparatively higher severity of stem rust was recorded (due to the heavy disease pressure), resulting in grain yield loss of up to $15.8 \%$. Loss in grain yield was generally higher at Agarfa than at Sinana during both seasons, which correspond to the higher disease severity at Agarfa.

Unlike grain yield, losses in TKW due to stem rust were higher for variety Maddawalabu than 
Sirbo. The disease has resulted in TKW loss of up to $25.4 \%$ on the variety Maddawalabu, while maximum loss in TKW of variety Sirbo was $20.1 \%$. Varieties might differ in the effect of the disease on other yield components too. A 37\% loss in number of kernels per spike was reported for stripe rust of wheat in Bale (Hailu and Fininsa, 2007). In all the varieties, only the weekly fungicide treatment significantly affected grain yield perhaps, at least partly, due to the staggered start of the sprays after disease appearance. However, the 14 days interval fungicide treatment also significantly increased grain yield of variety Sirbo during both crop seasons under high disease pressure at Agarfa, suggesting that reduced frequency of fungicide sprays has a potential to control the disease particularly had the first spray been made at disease onset as in the case of the weekly sprays. In addition, yield from fungicide sprayed plots was invariably higher than unsprayed plots. Cost-benefit analysis needs to be done to achieve economic use of fungicides for the management of stem rust.

\section{CONCLUSION}

Although stem rust appears late during the crop season, it could develop to severe epidemic levels and could be an important factor limiting bread wheat production in Bale highlands of Ethiopia. Local variations in severity of the disease is perhaps related to differences in weather conditions. Despite variations among varieties, the three varieties are attacked by stem rust in the absence of fungicide application. There is an urgent need for developing varieties resistant to the existing stem rust pathotypes. The fungicide treatments were effectiveness in reducing disease severity and improving crop yield. Further studies are necessary on timing and effectiveness of reduced fungicide sprays (14 or 21 days interval). Information on the economic benefits of fungicide interventions is also desired.

\section{ACKNOWLEDGEMENTS}

The study was supported by the Ethiopian Agricultural Research Organisation and Oromia Institute of Agricultural Research.

\section{REFERENCES}

Badebo, A. 2002. Breeding bread wheat with multiple disease resistance and high yielding for the Ethiopian highlands: Broadening the genetic base of yellow rust and tan spot resistance. Ph.D. Thesis, Georg-August University of Goettingen, Germany. 115 pp.

Beard, C., Jayasena, K., Thomas, G. and Loughman, R. 2004. Managing stem rust of wheat. Farmnote 73, State of Western Australia. http://www.agric.wa.gov.au. Accessed 6 February 2009.

Berger, R.D. 1981. Comparison of the Gompertz and logistic equation to describe plant disease progress. Phytopathology 71: 716-919.

Buchenauer, H. 1987. Modern selective fungicides: Properties, application, mechanism of action. Jena (GDR): VEB Gustav Fischer Verlag. Chapter 6, Mechanism of action of triazolyl fungicides and related compounds. pp. 205-232.

Campbell, C.L. 1998. The Epidemiology of Plant Diseases. London: Kluwer Academic Publishers. Chapter 9: Disease Progress in time: Modelling and data analysis. pp. 181206.

CIMMYT. 2005. Sounding the alarm on global stem rust: an assessment of race Ug99 in Kenya and Ethiopia and the potential for impact in neighbouring regions and beyond. Expert Panel Report. International Center for Maize and Wheat Improvement (CIMMYT), Mexico. 26p.

Everts, K.L. 2002. Reduced fungicide applications and host resistance for managing three diseases in pumpkin grown on a no-till cover crop. Plant Disease 86:1134-1141.

Hailu, D. and Fininsa, C. 2007. Relationship between stripe rust (Puccinia striiformis) and grain quality of bread wheat (Triticum aestivum) in the highlands of Bale, southeastern Ethiopia. International Journal of Food, Agriculture and Environment 5: 2430.

IRRI. 2003. IRRISTAT 4.3 for windows developed by the Biometrics and Bioinformatics Units. Manila, Philippines: International Rice Research Institute. 
Jeger, M.J. 2004. Analysis of disease progress as a basis for evaluating disease management practices. Annual Review of Phytopathology 42: 61-82.

Leonard, K.J. and Szabo, L.J. 2005. Stem rust of small grains and grasses caused by Puccinia graminis. Molecular Plant Pathology 6: 99111.

Luig, N.H., 1985. Cereal rusts, Vol. II: diseases, distribution, epidemiology and control. Orlando (FL): Academic Press. Chapter 8: Epidemiology in Australia and New Zealand. pp. 301-328.

Peterson, R.F., Campbell A.B. and Hannah, A.E. 1948. A diagrammatic scale for estimating rust intensity on leaves and stems of cereals. Canadian Journal of Research 26: 496-500.

Pretorius, Z.A., Singh, R.P., Wagoire, W.W. and Payne, T.S. 2000. Detection of virulence to wheat stem rust resistance gene $S r 31$ in Puccinia graminis f.sp. tritici in Uganda. Plant Disease 84: 203 (Abstract).

Roelfs, A.P. 1985a. The cereal rusts, Vol. II: diseases, distribution, epidemiology and control. Orlando (FL): Academic Press. Chapter 1, Wheat and rye stem rust; p. 3-37.

Roelfs, A.P. 1985b. The cereal rusts, Vol. II: diseases, distribution, epidemiology and control. Orlando (FL): Academic Press. Chapter 13, Epidemiology in North America. pp. 403-434.

SARC. 2004. Progress Reports for the Period 2002-2004, Pathology Department, Sinana Agricultural Research Centre, Sinana, Bale, Ethiopia.

Tadesse, K. 2005. Temporal development of stem rust (Puccinia graminis f.sp. tritici) and its effect on grain yield and protein content of bread wheat in Bale, Ethiopia. M.Sc. Thesis, Haramaya University, Ethiopia.

van der Plank, J.E. 1963. Epidemiology of plant disease. New York and London: Academic Publishers. 206p.

Wanyera, R., Kinyua, M.G., Jin, Y. and Singh, R.P. 2006. The Spread of Stem Rust Caused by Puccinia graminis f. sp. tritici, with Virulence on Sr31 in Wheat in Eastern Africa. Plant Disease 90: 113.

Wilcoxson, R.D., Skovmand, B. and Atif, A.H. 1975. Evaluation of wheat cultivars ability to retard development of stem rust. Annals of Applied Biology 80: 275-2181.

Zadoks, J.C., Chang, T.T. and Kanzak, C.F. 1974. A decimal code for the growth stage of cereals. Weed Research 14: 415-421. 